\title{
Estimation of Net Radiation in Three Different Plant Functional Types in Korea
}

\author{
Hyojung Kwon* \\ Global Environment Lab., Dept. of Atmospheric Sciences, Yonsei University, Seoul 120-749, Korea \\ (Received June 22, 2009; Revised June 25, 2009; Accepted June 25, 2009)
}

\section{한국의 세 개의 다른 식생기능형태에서의 순복사 추정}

\author{
권 효 정* \\ 연세대학교 대기과학과/지구환경연구소 \\ (2009년 6월 22일 접수; 2009년 6월 25일 수정; 2009년 6월 25일 수락)
}

\begin{abstract}
Net radiation $\left(R_{N}\right)$ is a driving force of biological and physical processes between the surface and the atmosphere and its knowledge is critical to weather forecasting and water resource management. The measurement of $\boldsymbol{R}_{N}$ is, however, scarce and it is typically estimated from an empirical relationship. This study presented two different methods of $\boldsymbol{R}_{N}$ estimation over three major plant functional types (i.e., a deciduous forest, a coniferous forest, and a farmland) in Korea. One is a linear regression method between $\boldsymbol{R}_{N}$ and solar radiation and the other is a radiation balance method. The two methods were examined using the data collected in 2008 at the three sites. Based on the linear regression method over a year, $R_{N}$ was $70 \%$ of the incoming shortwave radiation $\left(R_{S} \downarrow\right)$ for a deciduous forest, $79 \%$ for a coniferous forest, and $64 \%$ for a farmland, indicating that the relationship was plant functional type-specific. For the radiation balance method, the inclusion of longwave radiation component slightly improved $R_{N}$ estimations. Overall, there was a good agreement between the observed and the estimated $\boldsymbol{R}_{N}$ from both methods, indicating a reliable applicability of the two methods in estimating $\boldsymbol{R}_{N}$.
\end{abstract}

Key words : Net radiation, Solar radiation, Empirical relationship, Plant functional types

\section{INTRODUCTION}

Net radiation $\left(R_{N}\right)$ is a driving force of biological and physical processes between the surface and the atmosphere. $\mathrm{R}_{\mathrm{N}}$ controls the distribution of sensible, latent, and ground heat fluxes over land and the oceanic heating that regulates long-term weather and climate variability over ocean. Therefore, knowledge on $R_{N}$ is critical for the surface energy cycle as well as climate related studies. There are 544 weather stations operated by Korea Meteorological Administration (KMA; KMA, 2008). Despite the importance of $R_{N}$ measurements, there are only 10 stations conducting $R_{N}$ measurements and 22 stations conducting solar radiation measurements (KMA, 2008).

Using the readily available observation data of solar radiation, $R_{N}$ can be estimated from it based on a simple linear relationship. Previous studies have presented some reliable estimations of $R_{N}$ using this method (Shaw, 1956; Davies, 1966; Alados et al., 2003). Other studies, however, indicate an important role of longwave radiation on $R_{N}$ estimation (Gay, 1971; Ellingson, 1995; Kjaersgaard et al., 2007; Tang and Li, 2008), which is ignored in the simple empirical relationship due to its small variation compared to the solar radiation. Several methods have been used to estimate long-

* Corresponding Author: Hyojung Kwon(hkwon@koflux.yonsei.ac.kr) 
wave radiation using surface meteorological and satellite observations. These relationships, however, are sitespecific due to different land surface types and thus empirical constants of the relationship may not be applicable to other sites.

In order to find the site-specific relationship in the major plant functional types (i.e., a deciduous forest, a coniferous forest, and a farmland) in Korea, this paper presented the empirical relationship derived from the observed $R_{N}$ and solar radiation. By using daily sum data over a year in 2008 at the three sites, all weather conditions were included to simplify the calculation of $R_{N}$ and to derive the relationship. $R_{N}$ was also estimated by considering the influence of albedo and longwave radiation.

\section{THE BASIC THEORY}

$R_{N}$ is given as the sum of the net shortwave radiation and the net longwave radiation:

$$
\begin{aligned}
R_{N} & =\left(R_{S} \downarrow-R_{S} \uparrow\right)+\left(R_{L} \downarrow+R_{L} \uparrow\right) \\
& =(1-\alpha) R_{S} \downarrow+R_{L N}
\end{aligned}
$$

where $R_{S} \downarrow$ is the incoming shortwave radiation, $R_{S} \uparrow$ is the outgoing shortwave radiation, $R_{L} \downarrow$ is the incoming longwave radiation, $R_{L} \uparrow$ is the outgoing longwave radiation, $\alpha$ is the surface albedo, and $R_{L N}$ is the net longwave radiation. Previous studies indicate that $\mathrm{R}_{\mathrm{LN}}$ remains small and constant compared to the large variation of $R_{S} \downarrow$ and thus $R_{L N}$ can be ignored (Gay, 1971). Eq. 1 can be rewritten as a simple linear regression:

$$
R_{N}=a R_{S} \downarrow+b
$$

Eq. 2 presents the generally accepted concept of the empirical regression linking $R_{N}$ and $R_{S} \downarrow$. The regression coefficients (i.e., $a$ and $b$ ) represent (1- $\alpha$ ) and $R_{L N}$ in Eq. 1, respectively. The advantage of Eq. 2 is its simplicity with one explanatory variable. However, some previous studies have indicated the possibly significant contribution of $R_{L}$ in estimating $R_{N}$ (e.g., Hong and Kim, 2008). Instead of calculating $R_{L} \downarrow$ and $R_{L} \uparrow$ separately, $R_{L N}$ can be calculated following Allen et al. (1998):

$$
R_{N}=\sigma\left[\frac{T_{\max }^{4}+T_{\min }^{4}}{2}\right]\left(0.34-0.14 \sqrt{e_{a}}\right)\left(1.35 \frac{R_{S} \downarrow}{R_{s 0}}-0.35\right)
$$

where $\sigma$ is the Stefan-Boltzmann constant, $\mathrm{T}_{\max }$ and $\mathrm{T}_{\min }$ are the maximum and minimum air temperatures $[\mathrm{K}], \mathrm{e}_{\mathrm{a}}$ is actual vapor pressure $[\mathrm{kPa}], \mathrm{R}_{\mathrm{S} 0}$ is clear-sky solar radiation calculated according to:

$$
R_{S 0}=\left(0.75+2 \cdot 10^{-5} z_{h}\right) R_{d}
$$

where $z_{h}$ is elevation above sea level at the site and $\mathrm{R}_{\mathrm{a}}$ is extraterrestrial radiation $\left[\mathrm{MJ} \mathrm{m}{ }^{-2} \mathrm{~d}^{-1}\right] . R_{a}$ is calculated following Allen et al. (1998):

$R_{a}=\frac{24(60)}{\pi} G_{s c} d_{r}\left[\omega_{s} \sin (\varphi) \sin (\delta)+\cos (\varphi) \cos (\delta) \sin \left(\omega_{s}\right)\right]$

where $G_{s c}$ is the solar constant $\left(=0.0820 \mathrm{MJ} \mathrm{m}^{-2} \mathrm{~min}^{-1}\right), d_{r}$ is the inverse relative distance Earth-Sun $(=1+0.33 \cos$ $(2 \pi \mathrm{J} / 365)$, where $\mathrm{J}$ is Julian day), $\omega_{s}$ is the sunset hour angle $(=\arccos (-\tan (\varphi) \tan (\delta)), \varphi$ is the latitude [rad], and $\delta$ is solar decimation $(=0.409 \sin (2 \pi \mathrm{J} / 365-1.39)$. In this study, the observed values of $R_{S} \downarrow, T_{\max }, T_{\min }, e_{a}$, and $\alpha$ were used to estimate $R_{L N}$ and $R_{N}$.

\section{EXPERIMENTAL SITE AND MEASUREMENTS}

\subsection{Site description}

The study was conducted at three KoFlux sites: the Gwangneung deciduous forest site (i.e., GDK site), the Gwangneung coniferous site (i.e., GCK site), and the Haeman farmland site (i.e., HFK site). The GDK and GCK sites are located in the west-central part of the Korean Peninsula $\left(37^{\circ} 45^{\prime} 25.37^{\prime \prime}\right.$ N, $127^{\circ} 9^{\prime} 11.62^{\prime \prime}$ E, 340 above m.s.l for the GDK site and $37^{\circ} 45^{\prime} 25.37^{\prime \prime} \mathrm{N}$, $127^{\circ} 9^{\prime} 11.62^{\prime \prime}$ E, 175 above m.s.l for the GCK site). These sites are located in a complex, hilly temperate forest catchment ( $\sim 220 \mathrm{ha})$ with an average slope of $15^{\circ}$ and are aparted $\sim 1.2 \mathrm{~km}$ from each site within the catchment (Fig. 1). The GDK site is dominated by an old natural forest of Quercus sp. and Carpinus sp. (80200 years old) while the GCK site is dominated by conifer plantation mainly known as Abies sp. Further description of these sites can be found in Kim et al. (2006) and Lee et al. (2007).

The HFK site is located near the southwestern coast

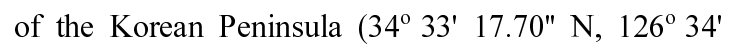
7.11" E, 13.74 m.s.l) with land cover types consisting of scattered rice paddies and various croplands. The major vegetation near the tower (within $\sim 300 \mathrm{~m}$ ) was seasonally cultivated crops such as beans, sweet potatoes, Indian millet, and sesame. Beyond this area, rice paddies prevailed except for in the northern area. The topography in the HFK site was relatively flat at a regional scale (e.g., $\sim 20 \mathrm{~km}$ ). Detailed descriptions of the HFK site can be found Ryu et al. (2008). 


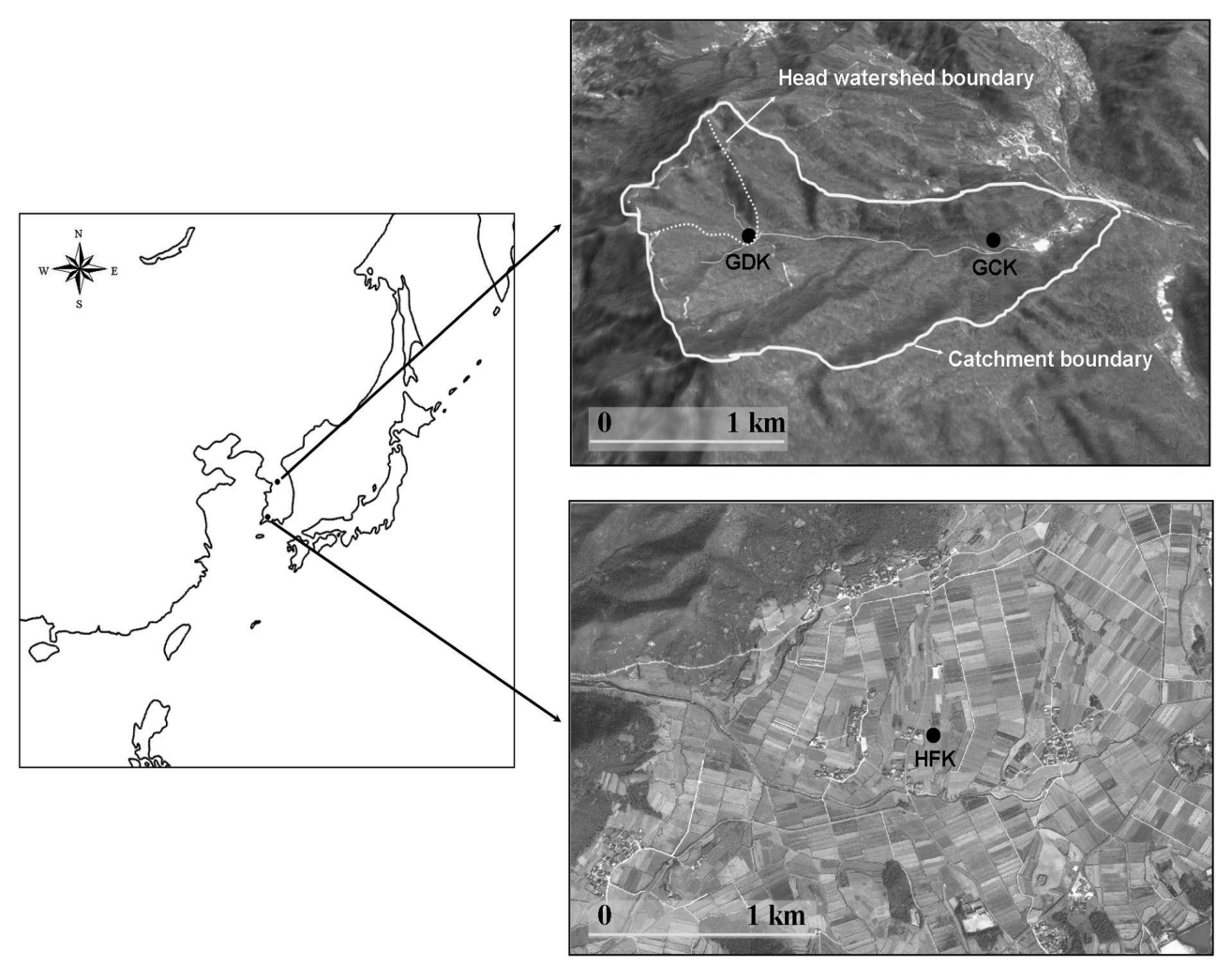

Fig. 1. Location of the study sites (adapted from Moon et al., 2007): the Gwangneung site (GDK for a deciduous forest and GCK for a coniferous forest; right top) and the Haeman site (HFK for a farmland; right bottom).

\subsection{Radiation measurements}

Radiation was measured using a net radiometer (Model CNR1, Kipp \& Zonen, Delft, the Netherlands) at $40 \mathrm{~m}$ for the GDK and GCK sites and $15 \mathrm{~m}$ for the HFK site. With CNR1, shortwave radiation (300-2800 $\mathrm{nm})$ and longwave radiation $(5-50 \mu \mathrm{m})$ were separately measured. $R_{S} \downarrow$ and $R_{S} \uparrow$ are measured by two CM2 pyranometers and from these two measurements, albedo (defined as the ratio of outgoing to incoming shortwave radiation) is determined. $R_{L} \downarrow$ and $R_{L} \uparrow$ are measured by two CG3 pyrgeometers. The radiation and other meteorological measurements (e.g., temperature) were conducted and stored on a datalogger (Model CR-23X at the GDK site and CR-5000s at the GCK and HFK sites, Campbell Scientific Inc., Logan, Utah, USA). Totals of $R_{N}$ for both daytime and 24-hr periods can be expressed as a function of total solar radiation (Ekern, 1965; Davies, 1965). In this study, over the 24-hr period, half-hourly data of $R_{N}$ and $R_{S} \downarrow$ for 2008 were summed to estimate daily values and the daily values were used to find the dependence between $R_{N}$ and $R_{S} \downarrow$.

\subsection{Error assessment}

In order to evaluate the predicted $R_{N}$, several statistical methods were used. Mean bias error (MBE) is the sum of the residuals. A large deviation from zero implies that the estimation generally overestimates or underestimates compared to the observed values. Root-mean-square-error (RMSE) is the standard deviation of the residuals and indicates a goodness of the prediction. An index of agreement $(d)$ is a measure of relative error in the estimation (Willmott, 1982). It ranges from 0 to 1 , where 0 describes complete disagreement and 1 describes complete agreement between the observation and estimation.

$$
\begin{aligned}
& \text { MBE }=\sum \frac{Y_{e s t}-Y_{o b s}}{n} \\
& \text { RMSE }=\sqrt{\sum \frac{\left(Y_{e s t}-Y_{o b s}\right)^{2}}{n}} \\
& d=1-\left[\frac{\sum_{i=1}^{N}\left(Y_{e s t_{i}}-Y_{o b s_{i}}\right)^{2}}{\sum_{i=1}^{N}\left(\left|Y_{e s t_{i}}^{\prime}\right|+\left|Y_{o b s_{i}}\right|^{2}\right.}\right], 0 \leq d \leq 1
\end{aligned}
$$


where $Y_{e s t_{i}}^{\prime}=Y_{e s t_{i}}-\bar{Y}_{o b s}$ and $Y_{o b s_{i}}^{\prime}=Y_{o b s_{i}}-\bar{Y}_{o b s}$ (here, overbar indicates an averaging operator). Empirical constants deduced from Eq. 2 using the data in 2008 were applied to the data in 2007 for the three plant functional types to estimate $R_{N}$ and to evaluate its applicability based on the error assessment.

\section{RESULTS}

$R_{S} \downarrow$ had a larger variation ( 5 to $25 \mathrm{MJ} \mathrm{m}^{-2}$ ) than $R_{S} \uparrow$ $\left(<4 \mathrm{MJ} \mathrm{m}^{-2}\right.$ ) throughout the year for all three sites (Fig. $2)$. As expected, the variations of $R_{L} \downarrow$ and $R_{L} \uparrow$ were not as prominent as $R_{S}$ with a range of 20 to $35 \mathrm{MJ} \mathrm{m}^{-2}$ for $R_{L} \downarrow$ and 25 to $40 \mathrm{MJ} \mathrm{m}^{-2}$ for $R_{L} \uparrow$. The magnitudes of $R_{L N}$ became larger in late fall and winter than in summer. On cloudy days and rainy days during the summer (e.g., around DOY 200 at the GDK site), the surface temperature was low, resulting in a lower $R_{L} \uparrow$ and $R_{L N}$. Albedo at the GDK site was less than 0.1 in winter and reached its maximum of 0.17 in spring (i. e., around DOY 135) when leaf area index was maximum. At the GCK site, albedo was almost constant (near 0.07 ) throughout the year. Albedo varied from 0.17 to 0.28 at the HFK site. These values of albedo in this study are similar to those reported for deciduous forest (0.1-0.2), coniferous forest (0.08; Betts and Ball, 1997), and cropland (0.2-0.4; Yemeni and Grace, 1995).

From the daily integrated values of $R_{N}$ and $R_{S} \downarrow$, the relationship between $R_{N}$ and $R_{S} \downarrow$ was determined over seasonal and annual periods at each site (Fig. 3 and Table 1). The empirical slope ( $a$ ) showed lower values in winter compared to those in other seasons for which

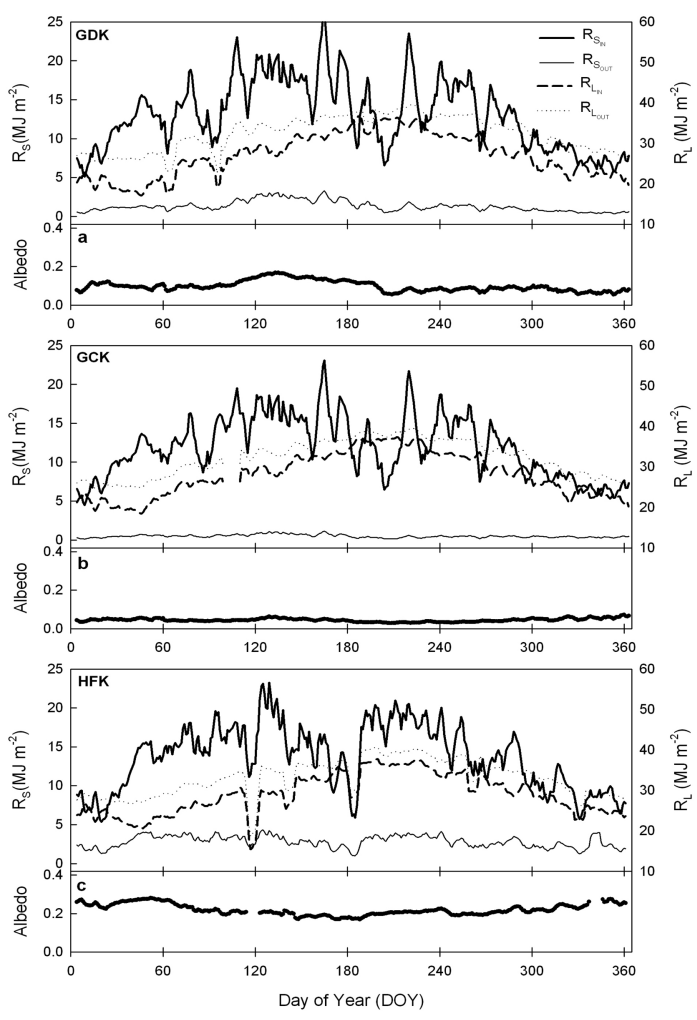

Fig. 2. Seasonal variation of radiations and albedo for a deciduous forest (GDK), a coniferous forest (GCK), and a farmland (HFK) in 2008. $R_{\text {SIN }}, R_{\text {SOUT }}, R_{\text {LIN }}$, and $R_{\text {LOUT }}$ indicate incoming shortwave, outgoing shortwave, incoming longwave, and outgoing longwave radiations, respectively.

similar values were obtained at each site. The variations in the slope did not correspond with those in
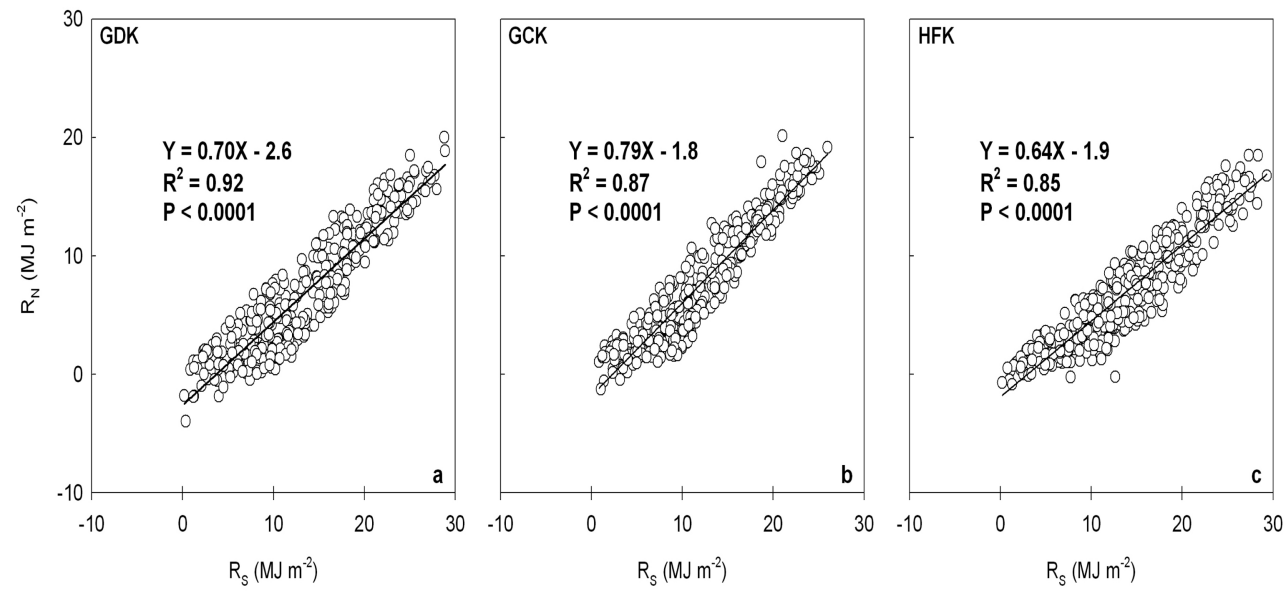

Fig. 3. Linear regressions between net radiation $\left(R_{N}\right)$ and shortwave radiation $\left(R_{S}\right)$ for a deciduous forest (GDK), a coniferous forest (GCK), and a farmland (HFK) in 2008. 
Table 1. The regressions coefficients of Eq. 2 for the three major plant functional types. $N$ is the number of the data points, $R_{S}$ is inconing shortwave radiation, $\mathrm{R}^{2}$ is regression coefficient, and $\mathrm{P}$ is probability

\begin{tabular}{|c|c|c|c|c|c|c|}
\hline \multirow{2}{*}{ Site (plant functional type) } & & \multirow{2}{*}{$\mathrm{N}$} & \multicolumn{2}{|c|}{$R_{R_{N}}=a R_{S} \downarrow+b$} & \multirow{2}{*}{$\mathrm{R}^{2}$} & \multirow{2}{*}{$\mathrm{P}$} \\
\hline & & & a & $\mathrm{b}\left[\mathrm{MJ} \mathrm{m}^{-2}\right]$ & & \\
\hline \multirow{5}{*}{ GDK (deciduous forest) } & Winter & 91 & 0.43 & -1.9 & 0.69 & $<0.0001$ \\
\hline & Spring & 88 & 0.61 & -0.8 & 0.94 & $<0.0001$ \\
\hline & Summer & 91 & 0.65 & -0.5 & 0.97 & $<0.0001$ \\
\hline & Fall & 91 & 0.65 & -2.7 & 0.83 & $<0.0001$ \\
\hline & Annual & 361 & 0.7 & -2.6 & 0.92 & $<0.0001$ \\
\hline \multirow{5}{*}{ GCK (coniferous forest) } & Winter & 90 & 0.5 & -1 & 0.74 & $<0.0001$ \\
\hline & Spring & 91 & 0.71 & -0.3 & 0.91 & $<0.0001$ \\
\hline & Summer & 91 & 0.72 & -0.8 & 0.98 & $<0.0001$ \\
\hline & Fall & 91 & 0.72 & -1.7 & 0.87 & $<0.0001$ \\
\hline & Annual & 363 & 0.79 & -1.8 & 0.87 & $<0.0001$ \\
\hline \multirow{5}{*}{ HFK (farmland) } & Winter & 89 & 0.35 & -0.6 & 0.7 & $<0.0001$ \\
\hline & Spring & 90 & 0.56 & -0.8 & 0.91 & $<0.0001$ \\
\hline & Summer & 92 & 0.64 & -0.01 & 0.97 & $<0.0001$ \\
\hline & Fall & 91 & 0.59 & -1.5 & 0.91 & $<0.0001$ \\
\hline & Annual & 362 & 0.64 & -1.9 & 0.85 & $<0.0001$ \\
\hline
\end{tabular}

albedo, although the slope was related to changes in albedo. The intercept $(b)$, which represents $R_{L N}$, had larger values in fall and winter in corresponding with the large $R_{L N}$ (Fig. 2), suggesting the relatively large contribution of $R_{L N}$ in determining $R_{N}$. The contribution of $R_{L N}$ on $R_{N}$ was quantified by comparing $b$ against $a^{*} R_{S} \downarrow$ over each season. For all three sites, $b$ was $<10 \%$ in spring and summer and $18 \sim 47 \%$ of $a^{*} R_{S} \downarrow$ in fall and winter.

Over the entire year, the estimates of the empirical slope were 0.70 for the GDK site, 0.79 for the GCK site, and 0.64 for the HKF site, indicating a significant difference between different plant functional types. The previous studies have reported the slope of 0.7 for a semi-arid shrub-land (Alados et al., 2003), 0.87 for forest, and 0.87 for cotton (Gay, 1971), 0.7-0.9 for coniferous forest (Jarvis et al., 1976), and 0.612 for West Africa and 0.617 for the world (Gay, 1971). The values of the intercepts were $-2.6 \mathrm{MJ} \mathrm{m}^{-2}$ for the GDK site, $-1.8 \mathrm{MJ} \mathrm{m}^{-2}$ for the GCK site, and $-1.9 \mathrm{MJ} \mathrm{m}^{-2}$ for the HFK site over the entire year. To test the predictive capability of these estimations (Eq. 2 and the regression coefficients), the coefficients were applied to the data set of $R_{N}$ and $R_{S} \downarrow$ in 2007 (which were not used in the regression) for the three sites to compare the estimated with the observed (Table 2). MBE was 0.2-1.9 $\mathrm{MJ} \mathrm{m}^{-2}$, RMSE was around $2 \mathrm{MJ} \mathrm{m}^{-2}$, and $d$ was $0.7-0.82$.
Table 2. Statistical parameters for error assessment at the three different sites: GDK is for a deciduous forest, GCK is for a coniferous forest, and HFK is for a farmland. MBE, RMSE, and $d$ indicate mean bias error, root-mean squareerror, and index of agreement, respectively.

\begin{tabular}{llccc}
\hline \hline & & GDK & GCK & HFK \\
\hline \multirow{3}{*}{ Eq. 1 } & MBE & 1.90 & 1.08 & 0.52 \\
& RMSE & 2.14 & 1.46 & 1.23 \\
& $d$ & 0.85 & 0.93 & 0.94 \\
\hline \multirow{3}{*}{ Eq. 2 } & MBE & -0.02 & 2.27 & 0.31 \\
& RMSE & 2.32 & 3.04 & 2.15 \\
& $d$ & 0.83 & 0.70 & 0.82 \\
\hline
\end{tabular}

*unit : [MJ m $\left.{ }^{-2}\right]$

Using Eq. 1 including albedo and the longwave components calculated from Eq. 3-5, $R_{N}$ was estimated and compared with the observed $R_{N}$ (Fig. 4). At the GDK and GCK sites, the patterns and magnitudes of the estimated $R_{N}$ were similar to those of the observed $R_{N}$ except for the late fall and winter periods. During these periods, the estimated $R_{N}$ was larger than the observed due to overestimation of $R_{L N}$ (i.e., $\sim 3.5 \mathrm{MJ} \mathrm{m}^{-2}$ for the GDK site and $2.5 \mathrm{MJ} \mathrm{m}^{-2}$ for the GCK site) (not shown). As indicated in the results of the simple regression method, the possible contribution of $R_{L N}$ in estimating $R_{N} \downarrow$ was relatively large during the fall and 

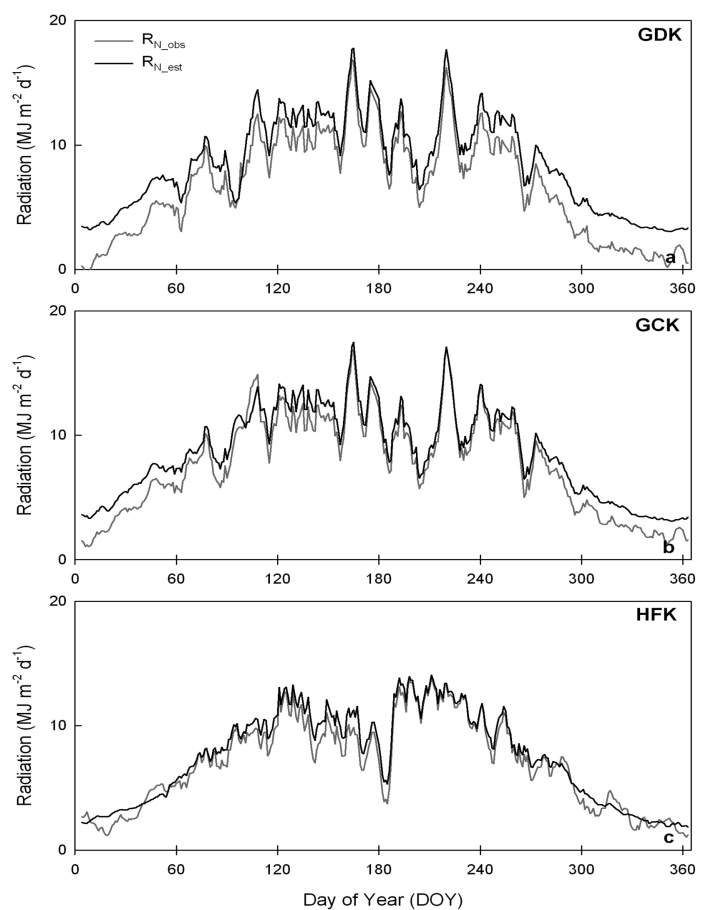

Fig. 4. Comparison of the observed net radiation $\left(\mathrm{R}_{\mathrm{N} \_ \text {obs }}\right)$ with the estimated net radiation $\left(\mathrm{R}_{\mathrm{N} \text { est }}\right)$ using Eq. 1 for a deciduous forest (GDK), a coniferous forest (GCK), and a farmland (HFK) in 2008.

winter periods when $R_{S}$ was small. At the HDK site, the estimated $R_{N}$ and the observed $R_{N}$ had a good agreement in terms of both the patterns and magnitudes. Statistical analysis suggests that the performance of the model (Eq. 1) had a slight improvement in the estimated $R_{N}$ with the lower values of $\mathrm{MBE}$ and RMSE and the enhanced $d$ values (Table 2).

\section{SUMMARY}

In this study, the site-specific relationship between net radiation and solar radiation were presented for the major plant functional types (i.e., a deciduous forest, a coniferous forest, and a farmland) in Korea using a simple linear regression with the observed data sets of net radiation and solar radiation. Also presented was the estimated net radiation by taking account for the variation of longwave radiation. For each plant functional type, the coefficients (i.e., slope and intercept) of the regression varied with season. Both methods exhibited the effect of longwave radiation on estimation of net radiation when solar radiation was relatively small in late fall and winter. Although the estimation of net radiation using the longwave radiation showed a slightly better performance than a simple empirical relationship, the good agreement between the estimation and observation from both methods indicates a reliable applicability of calculating daily net radiation based on either only solar radiation or solar radiation with other meteorological variables.

\section{ACKNOWLEDGEMENT}

This study is supported by a grant (Code: 1-8-3) from Sustainable Water Resources Research Center of $21^{\text {st }}$ Century Frontier Research Program, the Long-term Ecological Study and Monitoring of Forest Ecosystem Project of Korea Forest Research Institute, the A3 Foresight Program from the Korea Science and Engineering Foundation, and Korea Meteorological Administration. I would like to give thanks to the three reviewers who helped to improve the quality of the manuscript.

\section{적 요}

순복사는 지표와 대기간의 생물학적/물리적 과정을 일으키는 주요 원인이며 순복사에 대한 정확한 정보는 기후 예측뿐만 아니라 수자원관리에 중요한 역할을 한 다. 그러나 실제 순복사 관측을 하는 지점은 매우 적 으며 일반적으로 순복사는 단순 경험방정식으로부터 추 정된다. 이 연구에서는 한국의 세 개의 다른 식생기능 형태(예, 혼합림, 침엽수림, 그리고 농경지)에서 순복사 를 추정하는 두 방법을 제시하였다. 첫번째 방법은 순 복사와 전천일사의 관계를 선형회귀식으로 나타낸 방 법이고 두번째 방법은 복사수지방정식을 사용한 방법 이다. 세 개의 다른 식생기능형태에서 관측된 2008년 자료를 두 방법에 적용하여 순복사를 추정하였다. 일년 자료를 사용하여 선형회귀식을 적용한 결과, 전천일사 에 대한 순복사의 비율은 혼합림에서는 $70 \%$, 침엽수 림에서는 $79 \%$, 그리고 농경지에서는 $64 \%$ 를 보였다. 이는 다른 식생기능형태에 따라 순복사와 전천일사의 관계가 달라짐을 보였다. 장파복사를 고려한 복사수지 방정식의 경우, 순복사 추정이 다소 향상되었다. 두 방 법 모두 관측된 순복사와 추정된 순복사가 잘 일치함 을 보였으며 이는 두 방법을 사용하여 순복사를 추정 할 수 있음을 보여준다. 


\section{REFERENCES}

Al-Yemeni, M., and J. Grace, 1995: Radiation balance of an alfalfa crop in Saudi Arabia. Journal of Arid Environment 29, 447-454.

Alados, I., I. Foyo-Moreno, F. J. Olmo, and L. AladosArboledas, 2003: Relationship between net radiation and solar radiation for semi-arid shrub-land. Agricultural and Forest Meteorology 116, 221-227.

Allen, R. G., L. S. Pereira, D. Raes, and M. Smith, 1998: Crop Evapotranspiration: Guidelines for Computing Crop Requirements. Irrigation and Drainage Paper, 56, Food and Agric. Organ. of the U.N., Rome.

Betts, A. K., and J. H. Ball, 1997: Albedo over the boreal forest. Journal of Geophysics 102(D24), 28, 901-28, 910.

Davies, J. A., 1965: The use of a Gunn-Bellani Distillator to determine net radiative flux in West Africa. Journal of Applied Meteorology 4, 547-549.

Davies, J. A., 1966: A note on the relationship between net radiation and solar radiation. Quarterly Journal of the Royal Meteorological Society 93, 109-115.

Ekern, P. C., 1965: The Fraction of Sunlight Retained as Net Radiation in Hawaii. Journal of Geophysical Research 70(4), 785-793

Ellingson, R. G., 1995: Surface longwave fluxes from satellite observations: A critical review. Remote Sensing Environment 51, 8997.

Gay, L. W., 1971: The regression of net radiation upon solar radiation. Archives for Meteorology Geophysics and Bioclimatology 19, 1-14.

Hong, J., and J. Kim, 2008: Simulation of surface radiation balance on the Tibetan Plateau. Geophysical Research Letter, 35, L08814, doi:10.1029/2008GL033613.

Korea Meteorological Administration, 2008: Annual climatological report. 304pp.

Kim, J., D. Lee, J. Hong, S. Kang, S.-J. Kim, S.-K. Moon,
J.-H. Lim, Y. Son, J. Lee, S. Kim, N. Woo, K. Kim, B. Lee, B.-L. Lee, and S. Kim, 2006: HydroKorea and CarboKorea: cross-scale studies of ecohydrology and biogeochemistry in a heterogeneous and complex forest catchment of Korea. Ecological Research 21, 881-889.

Kjaersgarrd, J. H., R. H. Cuenca, F. L. Plauborg, and S. Hansen, 2007: Long-term comparisons of net radiation calculation schemes. Boundary-Layer Meteorology 123, 417-431.

Lee, D., J. Kim, S.-J. Kim, S.-K. Moon, J. Lee, J.-H. Lim, Y. Son, S. Kang, S. Kim, K. Kim, N. Woo, B. Lee, and S. Kim, 2007: Lessons from cross-scale studies of water and carbon cycles in the Gwangneung forest catchment in a complex landscape of monsoon Korea. Korean Journal of Agricultural and Forest Meteorology 9, 149160.

Ryu, Y. S., Kang, S.-K. Moon, and J. Kim, 2008: Evaluation of land surface radiation balance derived from moderate resolution imaging spectroradiometer (MODIS) over complex terrain and heterogeneous landscape on clear sky days. Agricultural and Forest Meteorology 148, 1538-1552.

Shaw, R. H., 1956: A comparison of solar radiation and net radiation. Bulletin of the American Meteorological Society 37, 205-206.

Tang, B., and Z.-L. Li, 2008: Estimation of instantaneous net surface longwave radiation from MODIS cloud-free data. Remote Sensing Environment 112, 3482-3492.

Willmott, C. J., 1982: Some comments on the evaluation of model performance. Bulletin of the American Meteorological Society 63, 1309-1313.

Zhang, Y. Q., F. H. S. Chiew, L. Zhang, R. Leuning, and H. A. Cleugh, 2008: Estimating catchment vaporation and runoff using MODIS leaf area index and the PenmanMonetith equation. Water Resources Research 44, W10420, doi:10.1029/2007WR006563. 